\title{
UDC 7.038.6:141.78(045)
}

\section{M. MYKULANYNETS ${ }^{1 *}$}

1*Mukachevo State University (Mukachevo, Ukraine), e-mail l.mikulaninets@gmail.com, ORCID 0000-0002-6346-6532

\section{IMAGE OF HUMAN IN THE POSTMODERN EPOCH}

Purpose. Based on the study of philosophical anthropological concepts, to highlight the project of personality in different historical periods, to reveal the meaning of humanistic issues in the postmodern epoch, to identify the essential features of the image of human of the second half of the XX - the beginning of the XXI century. Theoretical basis. The methodological basis of the article is the principles of historicism, integrity, objectivity regarding the mastery of the issue of person's image in postmodernism. The research applied comparative-historical, culturological, analytical, axiological approaches to reveal the problem of individuality in the second half of the XX - the beginning of the XXI century. The theoretical basis of the article consists of scientific works in the field of philosophical anthropology, history, cultural studies, and aesthetics. Originality. The author revealed the peculiarities of transformation of the personality model from antiquity to postmodernism, specified the image of man of the second half of the XX - the beginning of the XXI century. Conclusions. The analysis of anthropological ideas of Western philosophy of different ages shows the variety of views about understanding the nature of the person, its complexity and ambiguity. In the epoch of postmodernism humanistic issues are of particular relevance, which is connected with social and political uncertainty, domination of mass consciousness, loss of national and cultural identity. The image of a person of this period is deprived of a solid foundation, it is blurred and relative. The destruction of faith in the absolute in the context of the second half of the twentieth century contributed to the formation of confidence in the interdependence of all things (including certain historical periods), raised the problem of the personality image to a new ontological level. Orientation in the achievements of European civilization, perception of its anthropological experience, intercultural dialogue contribute to the productive use of the achievements of mankind in order to understand the modern person and to form its adequate image. In its essence, postmodernism does not set the goal to realize a retrospection of subject type. However, separating from the cultural memory the excerpts of ideas about a person, by certain styles and directions, it builds on their formations its own eclectic image of the individual.

Keywords: image of human; postmodernism; anthropology; historical epochs; humanism; worldview

\section{Introduction}

Anthropology in the twentieth century made a significant contribution to the awareness of human nature, however, there were revealed certain limits of its understanding, which cannot be extended from the standpoint of classical philosophy. In postmodernism, humanism has been subjected to sharp criticism. Feeling of frustration, confusion, the absurdity of being, a playful and mocking attitude to life and the high ideals affirmed (at least at the level of assertion) European civilization led to a revised interpretation of the image of the individual and its concept.

Although postmodernism has declared itself as an ideological system since the second half of the twentieth century, it has not yet established itself as a holistic paradigm with well-defined views on eternal problems. This direction has cast doubt on the leading spheres of activity of the person, proclaimed a certain absurdity of existence, at the same time declaring the desire to "reopen" the subjective world of the individual, to find his lost "Self". Logic and rationalism, which were the basis of the modern era, are recognized as destroying human freedom and manifestations of violence against him.

Anthropological scientific inquiries of postmodernism gave rise to doubt on the dominant principles of humanism. Theorist of this period U. Eco suggested that the hero of this era feels very uncomfortable, he is lonely because he lost his spiritual orientation. Accordingly, the individual is afraid of being himself, seeking certain images and roles that would make him relevant 
and understandable to others, the same lonely and unknowable. Therefore, the personality of this time is difficult to understand at the level of philosophical ontological knowledge.

The theme of the person's essence activates such issues as: being, consciousness, integrity, etc. For their solution, modern humanities involve in dialogue religion, history, ethics, politics, sociology, psychology, cultural studies, etc. Their purpose is to restore the unity of man, to get as much information about him as possible in order to find the true "Self". It is a kind of perfect utopian idea of a future "monad" person, which is more a project than a real goal.

It can be stated that today philanthropic issues are revealed in various aspects: rethinking of the content and nature of the individual, the importance of religion and traditions in his formation, studying of different types of worldview and their impact on the person, reflecting of philosophical and cultural foundations of anthropological sciences, etc.

At the same time, the idea of the "death of man", which was expressed by M. Foucault in the twentieth century, is particularly relevant. The loss of subjectivity, the dependence of consciousness on social, political and mental factors are real threats posed by postmodernism.

A critical view of the individual in the second half of the twentieth century developed under the influence of the philosophy of F. Nietzsche, who opposed the tenets of modernity. The thoughts of the thinker have caused a duality in the perception of the modern hero. On the one hand, his value is his own potential, which contributes to the achievement of the true purpose of existence, on the other - he is constantly subject to attacks of illusions, fear, struggle for life and happiness.

F. Nietzsche's beliefs laid the foundations for the leading strategies of person interpretation that changed the limits of his existence: one emphasizes the possibilities of artistic worldview (J. Bataille, J. Lacan, M. Foucault); the other shatters the foundations of metaphysical thinking (M. Heidegger, J. Derrida, Y. Kristeva). The directions presented confirmed a contrasting view of the individual: he is no longer a hero but appears as a creature that lost his orienting points; personality is social, biological and mental in nature, but intersubjective in life.

Despite the fact that man, his relationship with society, the search for his own "Self" became the subject of study by many scientists (J. Baudrillard, R. Barthes, D. Derrida, J. F. Liotard, M. Foucault, M. Heidegger, etc.), the current stage of the development of the humanities requires the specification and objectification of homo sapiens model contained in the postmodern program.

\section{Purpose}

Based on the study of philosophical anthropological concepts, to highlight the project of personality in different historical periods, to reveal the meaning of humanistic issues in the postmodern epoch, to identify the essential features of the image of human of the second half of the $\mathrm{XX}$ - the beginning of the XXI century.

\section{Statement of basic materials}

The study of peculiarities of the type of postmodern person implies the researcher's address to the historical and cultural reconstruction of its ideal in certain historical periods. Human life can be interpreted as a kind of worldview, dialogue and mutual enrichment of different civilizations. There is a deep connection between the epochs, despite the fact that often each successive epoch denies the achievement of the previous one. Therefore, comprehension of the image of the 
person of the second half of the XX - beginning of the XXI century requires understanding of the formation and development of the fundamental elements of anthropological science.

The subject's model question was first raised in European philosophical thought in ancient times. In the works of eminent thinkers (Protagoras, Sophocles, Plato, Aristotle, etc.), this problem is considered in the aspect of domination of physicality. The perception of the flesh as a "face", identical to thinking and symbolizing the principle of beautiful individuality, is a formative element of this civilization. The person explicates in harmony with space and nature. This harmony builds the idea of a free individual. According to S. Baranov (2009): "The image of man is a certain expression of dignity and freedom, resilience to the blows of fate, internal change of man" (p. 7). However, the hero of this period is not free enough, he must obey to the power of the absolute. Ancient personality is a means that promotes connection to higher values, it does not yet have a sense of self-importance. However, ethical categories such as charity, humanism, good, etc., are already being developed into the historical stage, which testifies to the emergence of a new axiological orientation that laid the foundation for medieval philanthropic views.

The eminent thinker M. Berdyaev (1933) expressed an opinion explaining the reasons for the development of a new type of middle-aged individual: "Christianity freed man from the power of cosmic infinity, into which he was immersed in the ancient world, from the spirits and demons of nature. It put him on his feet, strengthened him, made him dependent on God, not on nature" (p. 36). Theocentric views of the Middle Ages affirm the idea of the person as the image and likeness of the Lord. Personality moves to the forefront, though submissive to Him, but has the right to be responsible for himself. This idea is a source of understanding of the religious anthropocentric concept. Inner existence is the centre of knowledge for the fathers of the church. The soul is higher than space, it is associated with the Creator. Therefore, asceticism, renunciation of everything external and secular become the basis of life. Man is interpreted in two dimensions he is free, immortal, God-like, the centre and purpose of the universe, but in consequence of the Fall, it is internally dissociated. That is, in the presented age, a type of believing subject appears, who lives righteously, directed to God - the source of creative activity.

The Renaissance proclaims new values, affirms a philanthropic system whose starting point was humanism - proclamation of the special purpose of the individual. It is based on three leading principles: liberation of man from rigid church dogmatism, awareness of his uniqueness, return to ancient ideals.

Pico della Mirandola (Italian Renaissance thinker) formulates a defining view of the individual: "... the human being is the intermediary between creatures ... set midway between fixed eternity and fleeting time" (Bragina, 2001, p. 331). This postulate makes the subject a certain centre that connects the ideological world and the material (which, unlike the Middle Ages, is no longer interpreted as inferior). Accordingly, all needs, physical and sensual components become equal. Anthropological philosophical pursuits of the Renaissance lead to the following questions: who is a person, is he insignificant or mighty? The desire to find answers to them is in the treatises of Francesco Petrarca "Remedies for Fortune Fair and Foul", Facio "Of the Excellences and Outstanding Character of Man", Lorenzo Valla "On pleasure. Of the True and the False Good", etc. They affirm the image of the hero, considered the measure of all things. He harmoniously combines natural and social phenomena, nobility, divine basis, pure soul, beautiful body, morality, fight for good and justice. An individual is like God in that he is capable of creative selfdetermination, universal, not limited. 
Baroque is a type of culture that originated in Europe in the seventeenth century, defining a new stage in the development of civilization. It develops a kind of doctrine of the world and the personality, which, though based on the modified ideas of previous epochs, has a unique style. The image of the person is transformed, indicated by the tension of feelings. In this period philanthropic quest is growing, becoming ontological. Theorists of this direction have found contradictions between the person and society, nature, laws of existence.

The sense of contradiction separates the integrity of the individual. However, the time presented laid the groundwork for the emergence of another type of creative subject - capable of subtle feeling, suffering, experiencing, thinking and fantasizing.

As A. V. Lipatov states:

Baroque determined the problem of man in the philosophical, sociological, psychological aspect by scientists, ideologists, and artists. The aspirations of the era resulted in the psychological deepening of the conflict and the associated mainstreaming of the character, not as a type, but as a personality. The new concept of man became also reflected in the specificity of mass perception. The interest in the individual, the subjective, the unique in its singularity - all this became a sign of the times, which left the imprint on aesthetic tastes, literary teachings, the sphere of reception and the worldview in general. (Lipatov, 1977, p. 218)

The image of the individual is a complex phenomenon that is constantly evolving and changing. The tension of time brings theatricality, pathos and dynamism to its understanding.

Classicism with rational thinking transforms views on the concept of a person - autonomous one, who can deeply and soberly evaluate phenomena, make predictions about their consequences. He influences social and historical events through the power of intelligence. The ideal became a subject with strong spirit. He sacrifices his interests and even his life for the sake of the public good. The person is regarded as one of the pillars of the universe, a translator of the social system, which through the mind asserts higher moral values.

The era of the XIX century is characterized by a special understanding of personality and its capabilities. P. Gurevych notes:

Romantics have suggested that human existence is much more than its social dimension. The individual is cramped in the available historical space. He is easily transferred through imagination to other cultural 
worlds, many of which he creates himself. By denying reality, the romantic enters into unknown zones of his own being. Transforming reality, he embraces something unique, independent, which is inherent only to him as a living being. (Gurevych, 2001, p. 97)

The philosopher justifies the view that the subject is interesting due to his spiritual qualities, creative attitude to life.

Nineteenth-century anthropology assumes that a person is a microcosm, in which all the harmony of the cosmos is potentially embedded. Emphasis is placed on its uniqueness, and the tradition of individualization is deepened. I. Kant, I. Fichte, F. Schelling (the Doctrine of the Absolute) laid the foundations for understanding the essence of man. The ontological status of the subject is loneliness. He is disappointed in the world that surrounds him, so he sinks into selfobservation and seeks unity with the Divine Principle. Herewith, romantics have developed a productive idea of personality, according to which it is able to create its own civilizations that do not exist in reality, but transform its inner being and environment.

In the modernist period we can trace a significant development of culture, science, technology, medicine. The huge creative potential of the hero is revealed. The humanistic problem is becoming dominant. The reason for this situation is a departure from the spiritual origins, the affirmation of atheistic consciousness. One of the principles of the era is the denial of the "old", which leads to the shattering of the value system.

An important postulate for the comprehension of this period is the "death of God" and the idea of a "superhuman" expressed by Nietzsche. In light of them, a new image of the person the lonely one - begins to develop, moving away from society, with its own weighty inner world. The modernist conception of the individual suggests two approaches: objectivist and subjectivist ones. The first one comprehends the personality through the experimental study of its individual components (emotions, needs, ideals, etc.), the second one declares uniqueness, freedom, responsibility and the right to choose their own "Self".

Postmodernism was a testament to the crisis in the life of society and man in the second half of the XX - beginning of the XXI century. According to the researcher N. Amiri, it, unlike the modernism,

Emphasizes the importance of the socio-historical context. In postmodern art, the temporality and historical existence of man is a major issue of study. The contemporary artist tries to organize "disorganization" without a clear form of the world ... the postmodern artist knows that the result of his work is much more important and more valuable than his original intentions and desires. (Amiri, 2016, p. 1627) 
Modern humanities substantiate the view that an important feature of the era is game, irony, pluralism, multiculturalism, the parity of existence of different types of mentality. There is formed an idea of the person as one that simultaneously lives in all epochs, entertains with them, constructs his doctrine of being, based on typological figurative and historical collages of the individual. A retrospective analysis of the model of the individual until the second half of the XX century shows that each period offers its own vision, which in the second half of the twentieth century can be interpreted as one of the variants of the subject.

P. Pavlidis points out that

A person in postmodernism has great opportunities to engage himself in culture, thus developing as a personality in the context of world creativity. However, the modern hero develops in the aspect of the consumer of "cultural production", and therefore is not capable of conscious cultural activity that is based on eternal moral standards. Man is not fully realized, he remains infantile. (Pavlidis, 2005, p. 57)

The leading task of the individual is to learn the experience of previous times, to create his own image thereon - eclectic, repetitive, variational, cited and so on. The subject of the second half of the XX century demonstrates readiness for dialogue - with civilizations, styles, directions, he tries to recognize the value of any point of view, appeals to texts of different historical periods, and at the same time, playfully and mockingly refers to life and high standards of society. The person of postmodernism seeks to combine in his own "Self" the traits of all eras, and at the same time, his essence remains fragmentary and discrete.

In the second half of the twentieth century, traditional approaches to the individual do not study him, but model in accordance with the values of a certain time. The image of the person refers us to the relevant socio-historical and artistic situation, which helps to understand the mechanisms of constructing the content of the individual. Thus, from antiquity the modern hero takes the ideal of a beautiful appearance, which in postmodernism is understood as a cult of the body. According to J. Baudrillard:

Its (that is, the body) "new discovery" after the millennium era of Puritanism, which took place under the sign of physical and sexual liberation, is ubiquitous in advertising, fashion, mass culture (and especially the female body, it is necessary to understand why), the hygienic, dietary, therapeutic cult that surrounds it, the imposition of youth, elegance, masculinity or femininity, the care, regimes, sacrificial pursuits that are associated 
with it, the myth of Satisfaction - all today testifies that the body is the object of salvation. It literally replaced the soul in this moral and ideological function. (Baudrillard, 2006, p. 115)

The philosopher clearly reveals the transformation of the ancient idea of beautiful appearance, the shift of semantic accents that lead to the re-reading of this thought, the leveling of its original meaning.

Creating one of the variants of the image of man in postmodernism is also due to the appeal to the postulates of the Middle Ages, considered in the typological dichotomous proximity. Problems raised by the second half of the twentieth century: "death of God", "death of man", "end of history" can be solved through the return of the individual to the traditional religious truths of the Middle Ages: eternity of God, immortality of soul, infinity of history. However, this era includes various ideal constructions - mythologemes, ideologemes, theories that emerge as the subjective mode of thinking and feelings of the modern individual. Thus, the principles of medium aevum demonstrate their vitality in solving the questions of finding the sense of life, holistic and harmonious existence, giving certain completeness and unity to a destructive type of postmodern person.

The time of ancient Greece gave origin to philanthropic thought, which became dominant in the Renaissance. The anthropological crisis of the turn of the XX - XXI centuries was manifested through the conflict of humanism and anti-humanism. It is a testimony to the basic ideological oppositions of human existence: person - God, reason - faith, rationalism - irrationalism, traditions - innovations, etc. Proponents of each direction bring to the level of social consciousness the hopes and fears of the society, influence the development of the outlook and axiological ideas of the individual. The consequence of this confrontation is the communication between the philosophical, religious and secular traditions of different eras, which in postmodernism facilitates a person's choice of his own image and concept of being.

Aesthetics of the baroque in the characterization of the subject received certain formative features. Theatricality, which was one of the dominant qualities of the XVII - XVIII centuries, is understood in the second half of the twentieth century as an aesthetic category. It is connected with the understanding of social and internal life of the individual in the context of the playing space, where he can simultaneously feel in different roles and model situations under the laws of a certain action that is aimed at the viewer (Bazaluk, 2017). Entertainment during this period creates a mosaic picture of the environment, combines incompatible phenomena. Anthropology, based on baroque allusions, irony, game, perception of the world as chaos, seeks landmarks that would construct the image of a hero who can live fully, free from the absurd wanderings in an endless space of variants of his own "Self".

One of the factors behind the transformation of postmodern philosophy is the critique of reason, which gives impetus to the development of the main irrational foundations of the second half of the twentieth century. The lack of a reasonable approach to being, the emphasis on the feelings, is a leading feature of a person of this period. Neglected structuring, substitution of science by scientific similarity, rejection of analyticity, normativity and orderliness are decisive for him. That is, the modern man affirms the "Self"-concept by contrasting himself with the ideas of classical philosophy. Although daily existence repeatedly shows us a subject that 
proclaims the dominance of rational thinking. This person is one that keeps everything under his control, he is the master of his life and calculates his every action. It shows a peculiar image of the individual, which completely curbed his own emotions, goes firmly to the goal money, success and glory. Thus, in postmodernism, we observe both antagonistic attitudes toward philanthropic ideas of the eighteenth century and their transformed implementation into present-day realities.

The main categories of romanticism - detachment from the outside world, loneliness, illusions and fantasies are getting a new interpretation in the second half of the XX century. The hero of the time is irrational, spontaneous, egotistical, that makes him similar to the subject of the XIX century. However, the difference is that he is constantly living in a situation of possible loss of his own identity, blurring of the individual. The problem of relations between the individual and the society in the second half of the XX - the beginning of the XXI century becomes a leading feature, it is often solved through the fantasy, game with dreams, departure to the invented worlds.

Postmodernism destroys the anthropological model of the early twentieth century. The transcendent idea of the F. Nietzsche's willed overman is replaced by the reconstruction of the real person. If the notion of "personality" was dominant in modernity, then in the second half of the XX century sociality prevailed. S. Kostyuchkov (2018) noted that "postmodern man is open to all, perceives the world as a symbolic space, not wanting to get into the content of things, the essence of phenomena, interpretation of images (representations) and meaning of symbols, choosing the symbolic, "sliding" (that is, light, not deep) being" (p. 104).

Modern homo sapiens becomes fragmentary, discrete, devoid of integrity. His image is shaped by contrasting the key principles of the modernist worldview. As O. Chistyakova (2016) rightly points out: "The man of modernism is an immanent "product" of his time with emerging conceptual justifications and narratives, and the person of postmodernism has an imprint of his epochal history and the radically changed state of society" (p. 996).

Thus, the study of the problem of human image in the second half of the XX - beginning of the XXI century revealed that there are two trends in present-day reflections. One illustrates the position of comparing the interpretations of the individual in different historical periods with his understanding in postmodernism, proving that the latter forms a unique type of person. It is much more complex, original and testifies to a qualitatively new development of civilization. The other justifies the personality as a certain social and biological model, constructed from the cultural experience of previous times. This collage subject independently chooses the era in which he lives, professed values, his image. Moreover, in certain situations of life, depending on the particular conditions, the doctrine of his own "Self" can be transformed.

Many concepts of the person declare the search for adequate and objective comprehension of the person, which in principle is impossible in postmodernism. None of the humanitarian knowledge programs examining this issue has a definitive scientific option. This situation is an indicator of subjectivity, any researcher dealing with anthropological issues creates by himself the image of the individual. On the one hand, there are simultaneously different epochs and their aesthetic, moral ideals; on the other, there is a re-reading of the postulates of each historical period on the principle of mirror reflection, at the level of opposition pairs: life - death, rational - irrational, spiritual - corporeal, eternal - temporary. 


\section{Originality}

The paper revealed the peculiarities of transformation of the personality model from antiquity to postmodernism, specified the image of man of the second half of the $\mathrm{XX}$ - the beginning of the XXI century.

\section{Conclusions}

The analysis of anthropological ideas of Western philosophy of different ages shows the variety of views about understanding the nature of the person, its complexity and ambiguity. In ancient times, he was generally understood as free, but limited by certain generic and biological factors, subject to the rule of the Absolute. In the Middle Ages, the central tenet of personality cognition is the God-likeness. Renaissance humanism is manifested in the harmonious synthesis of the spiritual and physical nature, material and spiritual values, temporal and eternal ideas. Baroque type of the subject demonstrates the complexity, tension and drama of his inner life. Classicism offers a rational type of individual, who by the power of his own mind can influence social processes. Romanticism focuses on the private world of the hero, his creative beginnings. In modernism, man is treated as a free and autonomous substance, although placed in society and to some extent subject to the laws of the latter.

In postmodernism, philanthropic topics are of particular relevance due to socio-political uncertainty, domination of the mass consciousness, loss of national and cultural identity. A person, independent and free from any norms and dogmas, is a model of that time. One of the options for his formation is the reconstruction of anthropological postulates of different historical periods and their transformed implementation into general practice. They become the basis in pursuit of integrity and freedom of the individual. At the same time, criticism and rejection of worldview models of previous epochs open alternative ways of understanding the meaning of a person, constructing his qualitatively new type in the second half of the $\mathrm{XX}$ - beginning of the XXI century.

The image of a postmodern person is deprived of a solid foundation, it is blurred and relative. It combines what was previously considered incompatible. This is due to the absence of a single philosophical and ideological core. The destruction of faith in the absolute in the context of this time contributed to the formation of confidence in the interdependence of all things (including different civilizations), raised the problem of the personality image to a new ontological level, stimulated the search for his unity. Orientation in the achievements of European civilizations, perception of their anthropological experience, intercultural dialogue contribute to the productive use of the achievements of homo sapiens in order to understand the modern person and to form its adequate image. In essence, postmodernism does not aim to retrospect the type of subject. However, separating from the cultural memory the excerpts of ideas about a person, by certain styles and directions, it builds on their formations its own eclectic individual.

Finally, it should be noted that this publication is not a full-scale study of the whole range of issues related to understanding the image of human in the postmodern era. The future detailed study of the personality model in different historical periods seems necessary to us in the context of interaction with the ideas of the second half of the XX - beginning of the XXI century. Contemporary philanthropic problems require a thorough research in terms of their impact on the development of a new socio-cultural situation. 


\section{REFERENCES}

Amiri, N. (2016). Modernism and postmodernism in architecture, an emphasis on the characteristics, similarities and differences. The Turkish Online Journal of Design, Art and Communication, 1626-1634. doi: https://doi.org/10.7456/1060agse/044 (in English)

Baranov, S. A. (2009). Antichnyy obraz cheloveka: Istoricheskiy smysl i sudba $v$ dialoge kultur. (Avtoreferat dissertatsii kandidata tekhnicheskikh nauk). Yaroslav-the-Wise Novgorod State University, Velikiy Novgorod. (in Russian)

Baudrillard, J. (2006). La société de consommation: Ses mythes et ses structures. Moscow: Respublika; Kulturnaya revolyutsiya. (in Russian)

Bazaluk, O. (2017). The Theory of Education: "Those Who Transform the Universe" (New Book Announcement). Future Human Image, 8, 9-13. (in English)

Berdyaev, N. (1933). Chelovek i mashina (Problema sotsiologii i metafiziki tekhniki). Put, 38, 3-38. Retrieved from http://krotov.info/library/02_b/berdyaev/1933_384.html (in Russian)

Bragina, L. M. (2001). Giovanni Pico della Mirandola. Oration on the Dignity of Man. In Anthology of the philosophy of the Middle Ages and the Renaissance (pp. 318-332). Moscow: OLMA-PRYESS. (in Russian)

Chistyakova, O. V. (2016). Postmodernism, Christian Patristics, and Values of Peace in the Modern Cultures In the Context of Educational Process. Proceedings of the 2016 2nd International Conference on Arts, Design and Contemporary Education, May 23-25, 2016, Moscow, 994-999. doi: https://doi.org/10.2991/icadce16.2016.244 (in English)

Gurevych, P. S. (2001). Filosofiya cheloveka (Pt. 2). Moscow: IFRAN. (in Russian)

Kostyuchkov, S. K. (2018). Different human images and anthropological colissions of post-modernism epoch: Biophilosophical interpretation. Anthropological Measurements of Philosophical Research, 13, 100-111. doi: https://doi.org/10.15802/ampr.v0i13.131967 (in English)

Lipatov, A. V. (1977). Formirovanie polskogo romana i evropeyskaya literatura: Srednevekove, Vozrozhdenie, Barokko. Moscow: Nauka. (in Russian)

Pavlidis, P. (2005). Lichnost v postmodernistskom vospriyatii. K protivorechiyam sovremennogo obrazovaniya. Innovatsii v obrazovanii, 6, 55-64. Retrieved from http://www.ilhs.tuc.gr/ru/Postmodernism_i_lichnost.htm (in Russian)

\section{LIST OF REFERENCE LINKS}

Amiri, N. Modernism and postmodernism in architecture, an emphasis on the characteristics, similarities and differences / N. Amiri // The Turkish Online Journal of Design Art and Communication. - 2016. P. 1626-1634. doi: https://doi.org/10.7456/1060agse/044

Баранов, С. А. Античный образ человека: исторический смысл и судьба в диалоге культур : автореф. дис. ... канд. техн. наук : 20.00.01 / Баранов Сергей Александрович ; Новгород. гос. ун-т им. Ярослава Мудрого. - Великий Новгород, 2009. - 18 с.

Бодрийяр, Ж. Общество потребления. Его мифы и структуры / Ж. Бодрийяр. - Москва : Республика : Культурная революция, 2006. - 269 с.

Bazaluk, O. The Theory of Education: "Those Who Transform the Universe" (New Book Announcement) / O. Bazaluk // Future Human Image. - 2017. - Vol. 8. - P. 9-13.

Бердяев, Н. Человек и машина (Проблема социологии и метафизики техники) [Электронный ресурс] / Н. Бердяев // Путь. - 1933. - № 38. - С. 3-38. - Режим доступа: http://krotov.info/library/02_b/ berdyaev/1933_384.html. - Название с экрана. - Дата обращения: 20.11.2019.

Брагина, Л. М. Джованни Пико делла Мирандола. Речь о достоинстве человека. Пер. с латин. / Л. М. Брагина // Антология философии средних веков и эпохи Возрождения. - Москва, 2001. - С. 318-332.

Chistyakova, O. V. Postmodernism, Christian Patristics, and Values of Peace in the Modern Cultures In the Context of Educational Process / O. V. Chistyakova // 2nd International Conference on Arts, Design and Contemporary Education (May 23-25, 2016). - Moscow, 2016. - P. 994-999. doi: https://doi.org/10.2991/icadce-16.2016.244

Гуревич, П. С. Философия человека / П. С. Гуревич. - Москва : ИФРАН, 2001 . - Ч. 2. - 209 с.

Kostyuchkov, S. K. Different human images and anthropological colissions of post-modernism epoch: biophilosophical interpretation / S. K. Kostyuchkov // Антропологічні виміри філософських досліджень. - 2018. Вип. 13. - С. 100-111. doi: https://doi.org/10.15802/ampr.v0i13.131967 
Липатов, А. В. Формирование польского романа и европейская литература: Средневековье, Возрождение, Барокко / А. В. Липатов. - Москва : Наука, 1977. - 300 с.

Павлидис, П. Личность в постмодернистском восприятии. К противоречиям современного образования [Электронный ресурс] / П. Павлидис // Инновации в образовании. - 2005. - № 6. - С. 55-64. - Режим доступа: http://www.ilhs.tuc.gr/ru/Postmodernism_i_lichnost.htm. - Название с экрана. - Дата обращения: 20.11.2019.

\author{
Л. М. МИКУЛАНИНЕЦЬ ${ }^{1 *}$ \\ ${ }^{1 *}$ Мукачівський державний університет (Мукачево, Україна), ел. пошта l.mikulaninets@gmail.com, \\ ORCID 000-0002-6346-6532
}

\title{
ОБРАЗ ЛЮДИНИ В ЕПОХУ ПОСТМОДЕРНІЗМУ
}

Мета. На основі вивчення філософських антропологічних концепцій висвітлити проект особистості в різні історичні періоди, розкрити зміст гуманістичної проблематики в епоху постмодернізму, виявити сутнісні особливості образу людини другої половини XX - початку XXI століття. Теоретичний базис. Методологічною основою статті є принципи історизму, цілісності, об’єктивності щодо вивчення питання образу персони в постмодернізмі. У досліджені застосовано порівняльно-історичний, культурологічний, аналітичний, аксіологічний підходи для розкриття проблеми індивідуальності у другій половині XX - початку XXI століття. Теоретичною базою публікації стали праці науковців у галузі філософської антропології, історії, культурології, естетики. Наукова новизна. Виявлено особливості трансформації моделі особистості від античності до постмодернізму, уточнено образ людини другої половини XX - початку XXI століття. Висновки. Аналіз антропологічних ідей західноєвропейської філософії різних епох показує розбіжність поглядів на розуміння сутності типу персони, іiі складність та неоднозначність. У постмодернізмі гуманістична тематика набуває особливої актуальності, що пов'язано з соціально-політичною невизначеністю, домінуванням масової свідомості, втратою національної та культурної ідентичності. Образ героя зазначеної доби позбавлений міцної основи, він розмитий і релятивний. Знищення віри в абсолюти у контексті другої половини ХX століття сприяло формуванню впевненості у взаємозалежності всього сущого (у тому числі певних історичних періодів), підняло проблему проекту індивідуума на новий онтологічний рівень. Орієнтація у здобутках європейської цивілізації, сприйняття іiі досвіду, міжкультурний діалог сприяють продуктивному використанню досягнень людства задля розуміння сучасної персони й формування іiї адекватного іміджу. По своїй суті, постмодернізм не ставить собі за мету здійснити ретроспекцію типу суб'єкта, однак, виділяючи з культурної пам'яті уривки уявлень про особистість, якими для нього є певні стилі й напрями, на їх утвореннях будує власний еклектичний образ індивідуума.

Ключові слова: образ людини; постмодернізм; антропологія; історичні епохи; гуманізм; світогляд

\author{
Л. М. МИКУЛАНИНЕЦ ${ }^{1 *}$ \\ ${ }^{1 *}$ Мукачевский государственный университет (Мукачево, Украина), эл. почта l.mikulaninets@gmail.com, \\ ORCID 0000-0002-6346-6532
}

\section{ОБРАЗ ЧЕЛОВЕКА В ЭПОХУ ПОСТМОДЕРНИЗМА}

Цель. На основе изучения философских антропологических концепций осветить проект личности в разные исторические периоды, раскрыть содержание гуманистической проблематики в эпоху постмодернизма, выявить сущностные особенности образа человека второй половины XX - начала XXI века. Теоретический базис. Методологической основой статьи являются принципы историзма, целостности, объективности в изучении вопроса образа персоны в постмодернизме. В исследовании применены сравнительно-исторический, культурологический, аналитический, аксиологический подходы к раскрытию проблемы индивидуальности во второй половине XX - начала XXI века. Теоретической базой публикации стали труды ученых в области философской антропологии, истории, культурологии, эстетики. Научная новизна. Выявлены особенности трансформации модели личности от античности до постмодернизма, уточнен образ человека второй поло- 
вины XX - начала XXI века. Выводы. Анализ антропологических идей западноевропейской философии разных эпох показывает многообразие взглядов на понимание сущности типа персоны, ее сложность и неоднозначность. В постмодернизме гуманистическая тематика получает особую актуальность, что связано с социально-политической неопределенностью, доминированием массового сознания, потерей национальной и культурной идентичности. Образ героя указанного времени лишен прочной основы, он размыт и релятивен. Уничтожение веры в абсолюты в контексте второй половины XX века способствовало формированию уверенности во взаимозависимости всего сущего (в том числе определенных исторических периодов), подняло проблему проекта индивидуума на новый онтологический уровень. Ориентация в достижениях европейской цивилизации, восприятие ее опыта, межкультурный диалог способствуют продуктивному использованию приобретений человечества для понимания современной персоны и формирования ее адекватного имиджа. По своей сути, постмодернизм не ставит целью осуществить ретроспекцию типа субъекта, однако, выделяя из культурной памяти отрывки представлений о личности, которыми для него являются определенные стили и направления, на их образованиях строит собственный эклектичный образ индивидуума.

Ключевые слова: образ человека; постмодернизм; антропология; исторические эпохи; гуманизм; мировоззрение

Received: 09.09.2018

Accepted: 13.11.2019 